\title{
Increasing length of an estradiol and progesterone timed artificial insemination protocol decreases pregnancy losses in lactating dairy cows
}

\author{
M. H. C. Pereira, ${ }^{*}$ A. D. P. Rodrigues, ${ }^{*}$ R. J. De Carvalho,† M. C. Wiltbank, $\neq$ and J. L. M. Vasconcelos $\S^{1}$ \\ *Aluno do Programa de Pós-Graduação em Zootecnia, Faculdade de Medicina Veterinária e Zootecnia-Universidade Estadual Paulista, \\ Botucatu 18618-000, Brazil \\ †Fazendas Reunidas ACP e Filhos, Minas Gerais, Carmo do Rio Claro 37150-000, Brazil \\ $\ddagger$ Department of Dairy Science, University of Wisconsin, Madison 53706 \\ §Department of Animal Production, São Paulo State University, Botucatu 18168-000, Brazil
}

\section{ABSTRACT}

Our hypothesis was that increasing the length of an estradiol and progesterone (P4) timed artificial insemination (TAI) protocol would improve pregnancy per artificial insemination $(\mathrm{P} / \mathrm{AI})$. Lactating Holstein cows (n $=759$ ) yielding $31 \pm 0.30 \mathrm{~kg}$ of milk $/ \mathrm{d}$ with a detectable corpus luteum (CL) at $\mathrm{d}-11$ were randomly assigned to receive TAI ( $\mathrm{d} 0$ ) following 1 of 2 treatments: (8d) $\mathrm{d}-10=$ controlled internal drug release (CIDR) and $2.0 \mathrm{mg}$ of estradiol benzoate, $\mathrm{d}-3=\mathrm{PGF}_{2 \alpha}(25 \mathrm{mg}$ of dinoprost tromethamine), $\mathrm{d}-2=\mathrm{CIDR}$ removal and $1.0 \mathrm{mg}$ of estradiol cypionate, $\mathrm{d} 0=\mathrm{TAI}$; or $(9 \mathrm{~d}) \mathrm{d}-11$ $=\mathrm{CIDR}$ and estradiol benzoate, $\mathrm{d}-4=\mathrm{PGF}_{2 \alpha}, \mathrm{d}-2$ CIDR removal and estradiol cypionate, d 0 TAI. Cows were considered to have their estrous cycle synchronized in response to the protocol by the absence of a CL at artificial insemination (d 0) and presence of a CL on d 7. Pregnancy diagnoses were performed on d 32 and 60 . The ovulatory follicle diameter at TAI (d 0$)$ did not differ between treatments $(14.7 \pm 0.39$ vs. $15.0 \pm 0.40$ $\mathrm{mm}$ for 8 and $9 \mathrm{~d}$, respectively). The $9 \mathrm{~d}$ cows tended to have greater $\mathrm{P} 4$ concentrations on $\mathrm{d} 7$ in synchronized cows $(3.14 \pm 0.18 \mathrm{ng} / \mathrm{mL})$ than the $8 \mathrm{~d}$ cows $(3.05 \pm$ $0.18 \mathrm{ng} / \mathrm{mL})$. Although the P/AI at d $32[45(175 / 385)$ vs. $43.9 \%(166 / 374)$ for $8 \mathrm{~d}$ and $9 \mathrm{~d}$, respectively] and $60[38.1(150 / 385)$ vs. $40.4 \%(154 / 374)$ for $8 \mathrm{~d}$ and $9 \mathrm{~d}$, respectively] was not different, the $9 \mathrm{~d}$ cows had lower pregnancy losses $[7.6 \%(12 / 166)]$ than $8 \mathrm{~d}$ cows $[14.7 \%(25 / 175)]$. The cows in the $9 \mathrm{~d}$ program were more likely to be detected in estrus [72.0\% (269/374)] compared with 8d cows [62\% (240/385)]. Expression of estrus improved synchronization $[97.4(489 / 501)$ vs. $81 \%$ (202/248)], P4 concentrations at d $7(3.22 \pm 0.16$ vs. $2.77 \pm 0.17 \mathrm{ng} / \mathrm{mL}), \mathrm{P} / \mathrm{AI}$ at $\mathrm{d} 32[51.2(252 / 489)$ vs. $39.4 \%(81 / 202)], \mathrm{P} / \mathrm{AI}$ at d $60[46.3(230 / 489)$ vs. $31.1 \%(66 / 202)]$, and decreased pregnancy loss $[9.3$

Received July 24, 2013.

Accepted November 8, 2013.

${ }^{1}$ Corresponding author: vasconcelos@fmvz.unesp.br
$(22 / 252)$ vs. $19.8 \%(15 / 81)]$ compared with cows that did not show estrus, respectively. Cows not detected in estrus with small $(<11 \mathrm{~mm})$ or large follicles $(>17 \mathrm{~mm})$ had greater pregnancy loss; however, in cows detected in estrus, no effect of follicle diameter on pregnancy loss was observed. In conclusion, increasing the length of the protocol for TAI increased the percentage of cows detected in estrus and decreased pregnancy loss.

Key words: length of the protocol, estrus, pregnancy loss

\section{INTRODUCTION}

Programs for estrous cycle synchronization have been used for reproductive management in many parts of the world. These programs involve a series of hormonal treatments designed to synchronize a follicular wave, synchronize corpus luteum (CL) function, and, finally, synchronize ovulation, allowing timed AI (TAI) without the need for detection of estrus (Pursley et al., 1997). Various hormones and timing of protocols have been used, with the most widely used programs using either estradiol (E2) or GnRH at the beginning of the protocol to synchronize emergence of a new follicular wave and E2 or GnRH at the end of the protocol to synchronize ovulation near TAI (Vasconcelos et al., 2011a; Wiltbank et al., 2011a).

Several studies have evaluated the effect of altering the time from initiation of CL regression until TAI on fertility during estrous cycle synchronization programs in beef (Meneghetti et al., 2009; Peres et al., 2009; Bridges et al., 2010) and dairy cattle (Peters and Pursley, 2003; Ribeiro et al., 2012; Pereira et al., 2013a). For example, in dairy cows, a significant $(P<0.01)$ linear trend of an increasing percentage of cows pregnant per AI (P/AI) with increasing time from treatment with prostaglandin $\mathrm{F}_{2 \alpha}(\mathbf{P G F})$, to induce CL regression, until treatment with $\mathrm{GnRH}$, to induce synchronized ovulation $(8.8 \%$ at $0 \mathrm{~h} ; 13.2 \%$ at $12 \mathrm{~h} ; 21.4 \%$ at $24 \mathrm{~h}$; $28.0 \%$ at $36 \mathrm{~h}$ ) was observed. In Bos taurus beef cattle, a summary of results from various studies done in the laboratory of Michael Day (Bridges et al., 2010) sug- 
gested that fertility increased as time from $\mathrm{PGF}_{2 \alpha}$ until GnRH increased. Similarly, in Bos indicus beef cattle synchronized with E2 and progesterone $(\mathbf{P} 4)$, treatment with $\mathrm{PGF}_{2 \alpha} 4 \mathrm{~d}$ before TAI produced an increase in $\mathrm{P} / \mathrm{AI}$ compared with $\mathrm{PGF}_{2 \alpha}$ treatment $2 \mathrm{~d}$ before TAI [time of controlled internal drug release (CIDR) removal and estradiol cypionate (ECP) treatment]. In suckled Bos indicus beef cattle with a CL $4 \mathrm{~d}$ before TAI, Meneghetti et al. (2009) reported an increase in $\mathrm{P} / \mathrm{AI}$ (50.3 vs. $36.1 \%$ ) when the $\mathrm{PGF}_{2 \alpha}$ was given $4 \mathrm{~d}$ before TAI rather than $2 \mathrm{~d}$ before TAI (time of CIDR removal and ECP treatment) of the protocol. In nonlactating Bos indicus beef cattle (Peres et al., 2009), treatment with $\mathrm{PGF}_{2 \alpha} 4 \mathrm{~d}$ before TAI resulted in lower $\mathrm{P} 4$ concentrations on the day of CIDR removal, a larger follicle at TAI, an increased percentage of cows that ovulated to the protocol ( $85.4 \%$ vs. $77.0 \%)$, and increased $\mathrm{P} / \mathrm{AI}(52.0$ vs. $36.4 \%$ for all cows; 60.9 vs. $47.2 \%$ for cows that ovulated) compared with cows treated with $\mathrm{PGF}_{2 \alpha} 2 \mathrm{~d}$ before TAI. In grazing dairy cows that were presynchronized with $2 \mathrm{PGF}_{2 \alpha}$ treatments, increasing the interval from $\mathrm{PGF}_{2 \alpha}$ until GnRH and TAI from 58 to $72 \mathrm{~h}$ increased $\mathrm{P} / \mathrm{AI}$ in a $5 \mathrm{~d}$ CoSynch TAI protocol (Ribeiro et al., 2012).

Recent studies from our laboratory evaluated the interval from $\mathrm{PGF}_{2 \alpha}$ until TAI in lactating dairy cattle synchronized with an E2 and P4-TAI protocol (Pereira et al., 2013a). Consistent with the results of previous studies using beef cattle, an increased interval between $\mathrm{PGF}_{2 \alpha}$ and TAI ( 2 vs. $3 \mathrm{~d}$ ) increased P/AI in cows that received TAI (19.2 vs. $30.0 \%$ at d 60 pregnancy diagnosis), with a more subtle effect in cows that received timed embryo transfer (33.5 vs. 37.9\%). The earlier $\mathrm{PGF}_{2 \alpha}$ treatment $(3 \mathrm{~d})$ resulted in a greater proportion of cows with low P4 concentrations $(\leq 0.09 \mathrm{ng} /$ $\mathrm{mL}$ ) at TAI. Reduced P4 concentrations at TAI were associated with increased fertility, as has been observed in previous studies using GnRH-based TAI protocols (Souza et al., 2007; Martins et al., 2011; Giordano et al., 2012). In addition, reducing time from $\mathrm{PGF}_{2 \alpha}$ until induced ovulation decreased E2 concentrations near TAI, increased short luteal phases, and, at times, decreased P4 concentrations after AI (Vasconcelos et al., 2001; Bridges et al., 2010). Thus, the improved fertility with a longer time period from induction of luteolysis with $\mathrm{PGF}_{2 \alpha}$ until induction of synchronized ovulation could be related to greater time for CL regression and, thus, lower P4 at TAI or, alternatively, greater time for follicle growth, increased ovulatory follicle size, and increased E2 before synchronized ovulation.

The main hypothesis for the current study was that increasing the length of an estrous cycle synchronization protocol by $1 \mathrm{~d}$ would result in ovulation of a larger follicle and increased fertility in lactating dairy cows. The extra day of protocol length was added in the presence of lower $\mathrm{P} 4$ by advancing the time when the P4-releasing vaginal implant was removed after $\mathrm{PGF}_{2 \alpha}$ treatment. Thus, the experimental design allowed greater time for follicle growth in a lower P4 environment, as well as a longer time for complete CL regression before removal of the $\mathrm{P} 4$ implant. In addition to the main hypothesis, we also hypothesized that cows ovulating small follicles would have reduced fertility in either protocol. This study used the E2 and $\mathrm{P} 4$-based TAI program that is commonly used in Brazil and many other parts of the world.

\section{MATERIALS AND METHODS}

This study used only cycling cows in the cooler time of the year in Brazil to optimize the opportunity to observe any effects of protocol length or follicle size on fertility. This experiment was conducted at 3 commercial dairy farms in Minas Gerais, Brazil, from June to November 2011. All animal procedures followed the recommendations of the Guide for the Care and Use of Agricultural Animals in Agricultural Research and Teaching (FASS, 1999). During the experimental period, cows were housed in freestall barns with access to an adjoining sod-based paddock. Throughout the experiment, cows were milked 3 times daily. All procedures, including injections, ovarian ultrasonography, pregnancy diagnosis, blood collection, and TAI, were performed while cows were restrained in self-locking head gates at the feedline. Cows were fed a TMR based on corn silage and Tifton hay as forages ad libitum with a corn-soybean meal-based concentrate and minerals and vitamins, which were balanced to meet or exceed the nutritional requirements of lactating dairy cows (NRC, 2001).

\section{Animals and Treatments}

This study used a total of 759 lactating Holstein cows that were synchronized with an E2 or P4-based TAI program that is commonly used in Brazil and many other parts of the world. At the beginning of the experiment $(\mathrm{d}-11)$, cows averaged $153 \pm 3.8$ DIM, yielding $31.0 \pm 0.30 \mathrm{~kg}$ of milk/d, with a BCS of $2.84 \pm 0.02[1$ (emaciated) to 5 (obese) scale; Wildman et al., 1982], a lactation number of $1.82 \pm 0.05$ [primiparous (1), n $=473$; multiparous $(\geq 2), \mathrm{n}=286]$, and had been bred $2.16 \pm 0.09$ times. Within each farm, cows were blocked by parity (primiparous and multiparous); all cows that were past the voluntary waiting period and not pregnant were used and randomized into the study, without regard to whether they had been previously used in the study. Within each block, 1,101 cows were scanned to 


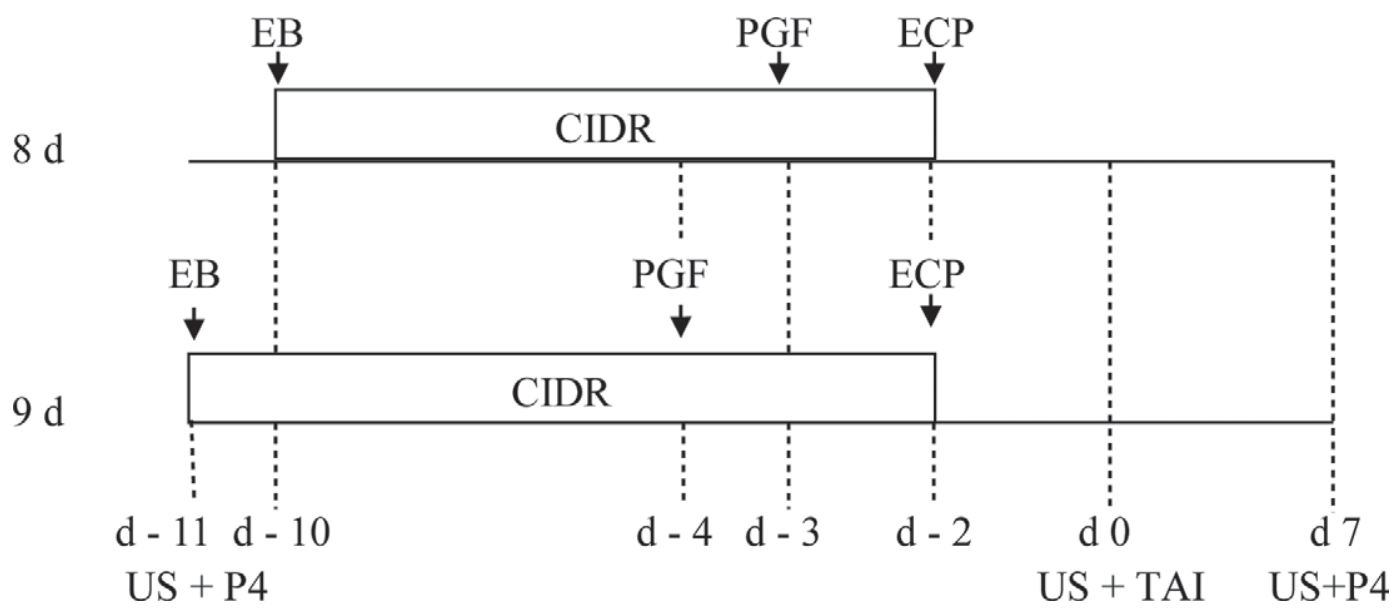

Figure 1. The ovaries were evaluated by ultrasound (US) in all cows on $d-11$ and cows with a detected corpus luteum were randomly assigned to begin the protocol on $\mathrm{d}-11(9 \mathrm{~d})$ or the next day $(8 \mathrm{~d})$. The 8 -d protocol included a controlled internal drug release (CIDR) and 2.0 $\mathrm{mg}$ of estradiol benzoate (EB); $7 \mathrm{~d}$ later cows received PGF; $24 \mathrm{~h}$ later the CIDR was removed and cows received $1.0 \mathrm{mg}$ of estradiol cypionate (ECP); finally, $48 \mathrm{~h}$ after CIDR removal, timed AI (TAI) was performed. The 9-d protocol included CIDR and $2.0 \mathrm{mg}$ of EB; $7 \mathrm{~d}$ later cows received $\mathrm{PGF}_{2 \alpha}$ and $48 \mathrm{~h}$ later the CIDR was removed and cows received $1.0 \mathrm{mg}$ of ECP; $48 \mathrm{~h}$ after CIDR removal, TAI was performed. $\mathrm{P} 4=$ blood sampling and analysis of progesterone concentration (sample on $\mathrm{d}-11$ and $\mathrm{d} 7$ ).

detect the presence of a detectable CL ( $\mathrm{d}-11)$; cows with a CL (759) were randomly assigned to receive TAI (d 0) with 1 of 2 treatments (Figure 1). The 8-d treatment (8d) consisted of an intravaginal CIDR P4 insert containing $1.9 \mathrm{~g}$ of P4 (Zoetis, São Paulo, Brazil) that was new, second use (previously used for $8 \mathrm{~d}$ ), or third use (previously used for $16 \mathrm{~d}$ ), and $2.0 \mathrm{mg}$ (i.m.) of estradiol benzoate (EB; $2.0 \mathrm{~mL}$ of Estrogin, Farmavet, São Paulo, SP, Brazil) on d -10; $25 \mathrm{mg}$ (i.m.) of dinoprost tromethamine $\left(\mathrm{PGF}_{2 \alpha} ; 5.0 \mathrm{~mL}\right.$ of Lutalyse, Zoetis) on $\mathrm{d}-3$; CIDR withdrawal and $1.0 \mathrm{mg}$ (i.m.) of estradiol cypionate (ECP; $0.5 \mathrm{~mL}$, Zoetis) on d -2 ; and TAI on $\mathrm{d} 0$. The 9-d treatment (9d) was a CIDR insert and $2.0 \mathrm{mg}$ (i.m.) of $\mathrm{EB}$ on d -11, Lutalyse on d -4 , CIDR withdrawal and $1.0 \mathrm{mg}$ of ECP on $\mathrm{d}-2$, and TAI on $\mathrm{d} 0$. The protocols started on different days; $9 \mathrm{~d}$ started on the day of ultrasonography (US; $\mathrm{d}-11$ ) and $8 \mathrm{~d}$ started $1 \mathrm{~d}$ later $(\mathrm{d}-10)$. The CIDR removal and ECP treatment were performed at $\mathrm{d}-2$ in both treatments (Figure 1). The TAI was performed on the same day in both treatments (d 0) by experienced technicians using commercial frozen-thawed semen from 23 different bulls. All cows were painted with chalk on their tail heads daily after the CIDR removal. Cows were considered in estrus when they were observed to stand after mounting or when chalk was completely removed.

\section{US}

In both groups, ovaries were evaluated by transrectal US (Aloka SSD-500 with a 7.5-MHz linear-array trans- ducer, Aloka, Tokyo, Japan) at d -11 to determine presence of a CL, at d 0 to measure the diameter of the largest follicle present, and $7 \mathrm{~d}$ after TAI to determine the presence of CL. Pregnancy diagnoses were performed by detection (transrectal US) of an embryo on d 32 or a fetus on d 60 . Cows were considered to have their estrous cycle synchronized in response to the protocol by the absence of a CL at AI (d 0) and presence of a CL on d 7. Pregnancy per AI was calculated dividing the number of pregnant cows on d 32 or 60 by the number of cows that were inseminated. Pregnancy loss from 32 to $60 \mathrm{~d}$ was calculated dividing the number of cows that lost their pregnancy by the number of pregnant cows at $\mathrm{d} 32$.

\section{Sample Collection}

Rectal temperature was measured in all cows using a digital thermometer (Jumbo Display Lab Thermometer, Delta Trak, Pleasanton, CA) in the morning at d 0 and 7 . Heat stress in cows was defined by rectal temperature $\left(<39.1^{\circ} \mathrm{C}=\right.$ no heat stress; $\geq 39.1^{\circ} \mathrm{C}=$ heat stress), given that $39.1^{\circ} \mathrm{C}$ is considered a threshold for heat stress in dairy cattle (Berman et al., 1985; West, 2003).

Milk production was measured daily between d 0 and 7 , and average daily production through this interval was used in the analysis. Blood samples were collected on $\mathrm{d}-11(\mathrm{n}=753)$ and $7(\mathrm{n}=742)$ by coccygeal venipuncture into commercial, 10-mL blood collection tubes (Vacutainer, Becton Dickinson, Franklin Lakes, NJ). After bleeding, tubes were placed on ice immediately, 
maintained at $4^{\circ} \mathrm{C}$ for $12 \mathrm{~h}$, and centrifuged at $1,500 \times$ $g$ for $15 \mathrm{~min}$ at room temperature for serum collection. Serum was stored at $-20^{\circ} \mathrm{C}$ for subsequent $\mathrm{P} 4$ analysis. Serum concentrations of P4 were analyzed using the Coat-A-Count solid phase 125I radioimmunoassay kit (DPC Diagnostic Products Inc., Los Angeles, CA) that had been previously validated in our laboratory (Santos and Vasconcelos, 2006). The intra-assay coefficient of variation was $3.98 \%$, the interassay coefficient of variation was $11.34 \%$, and the assay sensitivity was $0.02 \mathrm{ng} / \mathrm{mL}$.

\section{Statistical Analysis}

The experiment was analyzed as a complete randomized design. The binomial variables (estrus expression, estrous cycle synchronization, $\mathrm{P} / \mathrm{AI}$ on $\mathrm{d} 32$ and 60 , and pregnancy losses from 32 to $60 \mathrm{~d}$ ) were analyzed using the GLIMMIX procedures of SAS (SAS Institute Inc., Cary, NC) with farm as a random effect and other variables included in the models as appropriate, including effects of treatment, parity, and their interactions, as well as DIM, BCS, CIDR use, and milk yield as covariates. The continuous dependent variables (i.e., lactation number, DIM, BCS, milk production, previous AI number, temperature at AI, temperature at $\mathrm{d}$ 7, $\mathrm{P} 4$ concentrations at $\mathrm{d}-11$ and 7 , and follicular diameter at $\mathrm{d}$ 0) were analyzed using the MIXED procedures of SAS; other variables included in the models were the effects of treatment, parity, and their interactions, as well as DIM, BCS, CIDR use, and milk yield as covariables. The GLM procedure of SAS was used to determine if each individual measurement influenced pregnancy rates linearly, quadratically, cubically, or all. The LOGISTIC procedure was used to determine the intercept and slope(s) values according to maximum likelihood estimates from each significant continuous

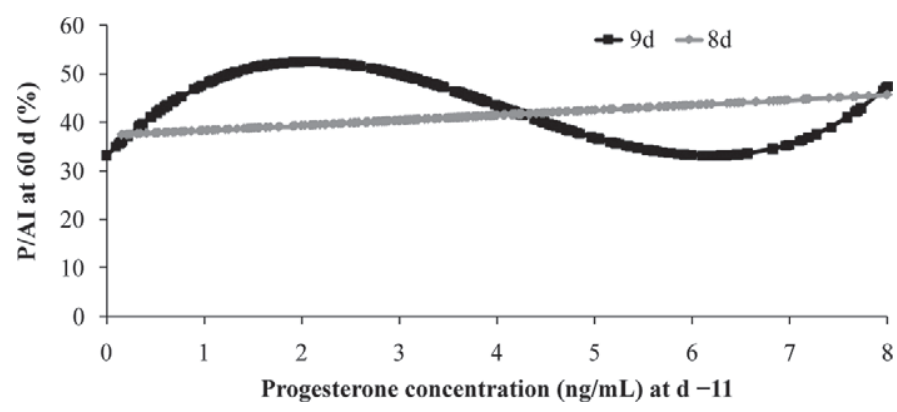

Figure 2. Treatment effects by progesterone concentration at the beginning of the protocol $(\mathrm{d}-11)$ on pregnancy per $\mathrm{AI}(\mathrm{P} / \mathrm{AI})$ rate at the d 60 pregnancy diagnosis in dairy cows that had their estrous cycle synchronized in response to the protocol (corpus luteum at d 7). An effect of progesterone concentration on $\mathrm{P} / \mathrm{AI}$ was observed in cows receiving the $9-\mathrm{d}(P=0.03)$ but not the $8-\mathrm{d}(P=0.88)$ protocol. order effect, and the probability of pregnancy was determined according Probability $=\left(\mathrm{e}^{\text {logisticequation }}\right) /(1+$ $\left.\mathrm{e}^{\text {logisticequation }}\right)$. Logistic curves were constructed according to the minimum and maximum values detected for each individual measurement.

Satterthwaite approximation was used to determine the denominator degrees of freedom for the tests of fixed effects with the random statement containing the effect of group. Covariables found to be not significant $(P$ $>0.10)$ were removed from the statistical model. The results are expressed as LSM \pm SEM for continuous variables. In all analyses, differences were considered significant when $P \leq 0.05$, whereas differences between $P>0.05$ and $P \leq 0.10$ were considered a statistical tendency.

\section{RESULTS}

As summarized in Table 1, no differences $(P>0.10)$ were found between treatment groups on lactation number, DIM, milk production, BCS, and previous AI number. All cows included in the study had a visible CL at the beginning of the study $(\mathrm{d}-11)$ and circulating $\mathrm{P} 4$ was not different $(P=0.20)$ between treatment groups (Table 1$)$. No difference $(P>0.10)$ was observed in temperature at $\mathrm{AI}$ or on $\mathrm{d} 7$ after $\mathrm{AI}$ between treatment groups (Table 1$)$. No difference $(P=0.30)$ was noted between treatment groups in average ovulatory follicle size in synchronized cows. However, a tendency was observed for greater circulating $\mathrm{P} 4$ on d 7 after AI in $9 \mathrm{~d}$ cows as opposed to $8 \mathrm{~d}$ cows, either when all cows $(P=0.09)$ were included or when only synchronized cows $(P=0.06)$ were included in the analysis (Table 1$)$.

The $9 \mathrm{~d}$ cows were more likely $(P<0.01)$ to be detected in estrus compared with $8 \mathrm{~d}$ cows (Table 2). A high percentage of cows had their estrous cycle synchronized to either protocol ( $>90 \%)$, with only 3 cows with a visible CL at the time of AI and 55 cows with no CL on d 7 after AI. No difference was observed between groups $(P=0.52)$ in the percentage of cows that had their estrous cycle synchronized (Table 2). The overall double ovulation rate was $13.6 \%$ with no treatment effects $(P=0.78)$ on the percentage of cows that had double ovulation (Table 2). Both protocols resulted in a high $\mathrm{P} / \mathrm{AI}$ for $\mathrm{d} 32$ pregnancy diagnosis in cows with their estrous cycle synchronized $(\sim 48 \%)$ and at $\mathrm{d} 60(>40 \%)$, with no difference $(P>0.10)$ between protocols (Table 2). Nevertheless, pregnancy losses between 32 and $60 \mathrm{~d}$ of pregnancy were decreased $(P=0.03)$ for $9 \mathrm{~d}$ cows $(7.8 \%)$ compared with $8 \mathrm{~d}$ cows (15.2\%; Table 2$)$.

Only cows with a CL detected by US at the beginning of the protocol were used in this study. The P4 concentration at the start of the protocol $(\mathrm{d}-11)$ had 
Table 1. Comparison of various measures for cows treated with protocols of either 8 or $9 \mathrm{~d}$ in length (LSM \pm SEM with $n$ in parentheses)

\begin{tabular}{|c|c|c|c|}
\hline \multirow[b]{2}{*}{ Item } & \multicolumn{2}{|c|}{ Protocol length } & \multirow[b]{2}{*}{$P$-value } \\
\hline & $8 \mathrm{~d}$ & $9 \mathrm{~d}$ & \\
\hline Lactation number ${ }^{1}$ & $1.76 \pm 0.68(385)$ & $1.88 \pm 0.70(374)$ & 0.21 \\
\hline $\mathrm{DIM}^{1}$ & $152.0 \pm 9.05(385)$ & $150.1 \pm 9.09(374)$ & 0.92 \\
\hline Milk production ${ }^{1}(\mathrm{~kg} / \mathrm{d})$ & $30.7 \pm 0.65(384)$ & $30.7 \pm 0.66(374)$ & 0.90 \\
\hline $\mathrm{BCS}^{1}$ & $2.85 \pm 0.04(385)$ & $2.85 \pm 0.04(374)$ & 0.83 \\
\hline Previous AI number ${ }^{1}$ & $2.06 \pm 0.32(385)$ & $2.06 \pm 0.32(374)$ & 0.99 \\
\hline Progesterone on $\mathrm{d}-11^{1}(\mathrm{ng} / \mathrm{mL}$; protocol start) & $3.92 \pm 0.35(382)$ & $4.14 \pm 0.35(371)$ & 0.20 \\
\hline Temperature $\left({ }^{\circ} \mathrm{C}\right)$ at $\mathrm{AI}^{1}(\mathrm{~d} 0)$ & $38.6 \pm 0.12(384)$ & $38.6 \pm 0.12(374)$ & 0.56 \\
\hline Temperature $\left({ }^{\circ} \mathrm{C}\right) 7 \mathrm{~d}$ post- $\mathrm{AI}^{1}(\mathrm{~d} 7)$ & $38.6 \pm 0.07(364)$ & $38.6 \pm 0.07(360)$ & 0.94 \\
\hline Ovulatory follicle $^{2}(\mathrm{~mm})$ & $14.7 \pm 0.39(312)$ & $15.0 \pm 0.40(280)$ & 0.30 \\
\hline Progesterone at $\mathrm{d} 7^{1}(\mathrm{ng} / \mathrm{mL})$ & $2.88 \pm 0.20(377)$ & $3.07 \pm 0.20(364)$ & 0.09 \\
\hline Progesterone at d $7^{2}(\mathrm{ng} / \mathrm{mL})$ & $3.05 \pm 0.18(351)$ & $3.14 \pm 0.18(336)$ & 0.06 \\
\hline
\end{tabular}

no effect $(P=0.88)$ on $\mathrm{P} / \mathrm{AI}$ at $\mathrm{d} 60$ pregnancy diagnosis for $8 \mathrm{~d}$ cows; however, an effect $(P=0.03)$ of $\mathrm{P} 4$ concentration at $\mathrm{d}-11$ was found for $\mathrm{P} / \mathrm{AI}$ at $60 \mathrm{~d}$ in cows with their estrous cycle synchronized by the $9 \mathrm{~d}$ protocol (Figure 2). In cows with $\mathrm{P} 4<4.0 \mathrm{ng} / \mathrm{mL}$ at d -11 , the $9 \mathrm{~d}$ protocol tended $(P=0.10)$ to have greater $\mathrm{P} / \mathrm{AI}$ at $60 \mathrm{~d}[46.8(89 / 187)$ vs. $38.6 \%(77 / 192)$ for $9 \mathrm{~d}$ and $8 \mathrm{~d}$, respectively]. In cows with $\mathrm{P} 4 \geq 4.0 \mathrm{ng} / \mathrm{L}$ at d -11 , the $\mathrm{P} / \mathrm{AI}$ did not differ $(P=0.75)$ between treatments $[41.2(62 / 150)$ vs. $42.7 \%(68 / 159)$ for $9 \mathrm{~d}$ and $8 \mathrm{~d}$, respectively].

Treatment did not have an effect $(P=0.30)$ on average follicle diameter (Table 1); however, the distribution of follicle diameters was altered by treatment (Table 3). Although a similar percentage of small $(\leq 11$ $\mathrm{mm})$ and large $(>17 \mathrm{~mm})$ ovulatory follicles were observed, a greater percentage $(P=0.01)$ of $8 \mathrm{~d}$ cows had a medium follicle diameter $(11.1-17 \mathrm{~mm})$ compared with $9 \mathrm{~d}$ cows. Conversely, more $(P=0.02) 9 \mathrm{~d}$ cows had premature ovulation (ovulation before TAI) than 8d cows. Circulating P4 on d 7 after TAI (Table 3) increased $(P<0.01)$ with increasing follicle diameter at TAI. No differences $(P>0.10)$ in circulating P4 were observed between treatment groups in any of the follicle classes, except for greater $(P<0.01) \mathrm{P} 4$ in prematurely-ovulating cows for $9 \mathrm{~d}$ versus $8 \mathrm{~d}$ cows. Follicle diameter at TAI affected $(P \leq 0.05) \mathrm{P} / \mathrm{AI}$ at 32 and $60 \mathrm{~d}$ in both treatments for cows that had their estrous cycle synchronized (Table 3; Figure 3). Lower fertility was noted in cows that ovulated too small $(\leq 11$ $\mathrm{mm})$ or too large $(>17 \mathrm{~mm})$ follicles (Figure 3$)$. The cows with premature ovulation had similar fertility as the cows that ovulated large $(>17 \mathrm{~mm})$ follicles. The pregnancy losses did not differ $(P=0.96)$ between

Table 2. Effects of protocol length on expression of estrus, estrous cycle synchronization, double ovulation, and pregnancy per AI (P/AI) for all cows and only for cows that had their estrous cycle synchronized (LSM with $\mathrm{n} / \mathrm{n}$ in parentheses)

\begin{tabular}{|c|c|c|c|}
\hline \multirow[b]{2}{*}{ Item } & \multicolumn{2}{|c|}{ Protocol length } & \multirow[b]{2}{*}{$P$-value } \\
\hline & $8 \mathrm{~d}$ & $9 \mathrm{~d}$ & \\
\hline Expression of estrus $^{1}$ & $63.4(240 / 385)$ & $73.0(269 / 374)$ & $<0.01$ \\
\hline Estrous cycle synchronization $^{2}$ & $92.8(352 / 379)$ & $91.5(339 / 370)$ & 0.52 \\
\hline Double ovulation $^{1}$ & $12.3(43 / 352)$ & $15.1(51 / 337)$ & 0.26 \\
\hline \multicolumn{4}{|l|}{$\mathrm{P} / \mathrm{AI}^{1}$} \\
\hline At $32 \mathrm{~d}$ & $45.0(175 / 385)$ & $43.9(166 / 374)$ & 0.77 \\
\hline At $60 \mathrm{~d}$ & $38.1(150 / 385)$ & $40.4(154 / 374)$ & 0.52 \\
\hline Pregnancy loss & $14.7(25 / 175)$ & $7.6(12 / 166)$ & 0.04 \\
\hline \multicolumn{4}{|l|}{$\mathrm{P} / \mathrm{AI}^{2}$} \\
\hline At $32 \mathrm{~d}$ & $48.1(170 / 352)$ & $47.9(163 / 339)$ & 0.96 \\
\hline At $60 \mathrm{~d}$ & $40.5(145 / 352)$ & $43.9(151 / 339)$ & 0.37 \\
\hline Pregnancy loss & $15.2(25 / 170)$ & $7.8(12 / 163)$ & 0.03 \\
\hline
\end{tabular}

${ }^{1}$ All inseminated cows.

${ }^{2}$ Cows with no corpus luteum on d 0 and 1 or more visible corpus luteum on d 7 were considered synchronized and were used in this analysis. 
treatments in cows ovulating small follicles $(<11 \mathrm{~mm})$. However, in cows ovulating follicles between 11.1 and $17 \mathrm{~mm}$, the $9 \mathrm{~d}$ protocol tended to have lower $(P=$ $0.08)$ pregnancy loss. When cows that ovulated larger follicles were grouped with cows that had premature ovulation, the $9 \mathrm{~d}$ protocol tended $(P=0.08)$ to have lower pregnancy loss $[9.6(5 / 52)$ vs. $22.9 \%(8 / 35)$ for $9 \mathrm{~d}$ and 8d, respectively].

Expression of estrus (Table 4$)$ increased $(P<0.01)$ the percentage of cows with CL on $\mathrm{d} 7$, increased $(P$ $<0.01$ ) circulating $\mathrm{P} 4$ concentrations on $\mathrm{d} 7$, and increased $(P<0.01) \mathrm{P} / \mathrm{AI}$ at the $\mathrm{d} 32$ and 60 pregnancy diagnoses in synchronized cows in both treatments. No interaction was detected between expression of estrus and treatment for any of these variables. A greater pregnancy loss from 32 to $60 \mathrm{~d}(P<0.01)$ was observed in cows that did not show estrus.

Follicle diameter at TAI affected $(P<0.01) \mathrm{P} / \mathrm{AI}$ at the $\mathrm{d} 32$ and 60 pregnancy diagnoses in synchronized cows, independent of whether cows were detected in estrus (Figure 4). In cows not detected in estrus, the follicle diameter had an effect $(P=0.01)$ on pregnancy loss (Figure 5); however, in cows that were detected in

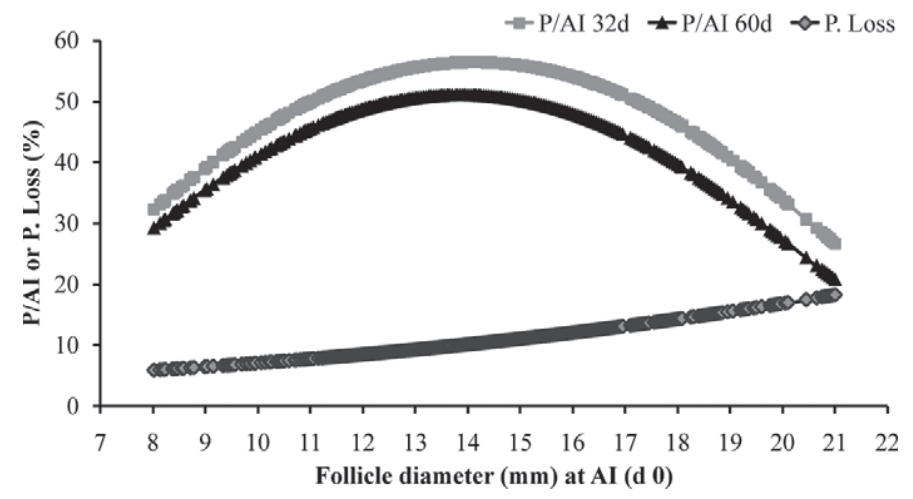

Figure 3. Effect of follicle diameter at time of AI (d 0) on pregnancy per $\mathrm{AI}(\mathrm{P} / \mathrm{AI})$ rate at 32 and $60 \mathrm{~d}$ and pregnancy loss (P. Loss) in dairy cows that had their estrous cycle synchronized in response to the protocol (corpus luteum at d 7). Significance was set at $P<0.01$ for $32 \mathrm{~d}, P<0.01$ for $60 \mathrm{~d}$, and $P=0.15$ for P. Loss.

estrus, the follicle diameter did not have effect $(P=$ 0.97) on pregnancy loss from 32 to $60 \mathrm{~d}$.

Heat stress was observed in $27 \%(196 / 723)$ of cows during the experim $=$ ent (at least one measurement $\geq$ $\left.39.1^{\circ} \mathrm{C}\right)$. Cows with heat stress had a similar $(P=0.80)$

Table 3. Effects of protocol length $(8$ or $9 \mathrm{~d})$ and follicle diameter at timed AI on progesterone $(\mathrm{ng} / \mathrm{mL})$ at d 7, pregnancy per AI (P/AI) at d 32, d 60, and pregnancy losses (32-60 d) for synchronized dairy cows (LSM with $\mathrm{n} / \mathrm{n}$ in parentheses)

\begin{tabular}{|c|c|c|c|c|c|}
\hline \multirow[b]{2}{*}{ Item } & \multicolumn{4}{|c|}{ Follicle diameter $(\mathrm{mm})$ at $\mathrm{d} 0$} & \multirow[b]{2}{*}{$P$-value } \\
\hline & $8-11$ & $11.1-17$ & $>17$ & Ovulated & \\
\hline \multicolumn{6}{|l|}{ Distribution $^{1}$} \\
\hline $8 \mathrm{~d}$ & $9(33 / 352)$ & $62(217 / 352)$ & $17(60 / 352)$ & $12(42 / 352)$ & - \\
\hline $9 \mathrm{~d}$ & $9(33 / 339)$ & $53(178 / 339)$ & $20(68 / 339)$ & $18(60 / 339)$ & - \\
\hline$P$-value & 0.87 & 0.01 & 0.29 & 0.02 & \\
\hline \multicolumn{6}{|l|}{ Estrus expression ${ }^{1}$} \\
\hline $8 \mathrm{~d}$ & $66.7(22 / 33)$ & $63.8(137 / 218)$ & $72.9(43 / 60)$ & - & 0.44 \\
\hline $9 \mathrm{~d}$ & $84.9(28 / 33)$ & $74.9(132 / 178)$ & $72.9(49 / 68)$ & - & 0.35 \\
\hline$P$-value & 0.08 & 0.02 & 0.99 & & \\
\hline $\begin{array}{l}\text { Progesterone at } \mathrm{d} 7^{1} \\
(\mathrm{ng} / \mathrm{mL})\end{array}$ & $2.67 \pm 0.22$ & $2.97 \pm 0.17$ & $3.40 \pm 0.19$ & $3.50 \pm 0.20$ & $<0.01$ \\
\hline $8 \mathrm{~d}$ & $2.57 \pm 0.27$ & $2.96 \pm 0.18$ & $3.43 \pm 0.23$ & $3.08 \pm 0.25$ & 0.01 \\
\hline $9 \mathrm{~d}$ & $2.78 \pm 0.26$ & $2.99 \pm 0.16$ & $3.37 \pm 0.21$ & $3.78 \pm 0.21$ & $<0.01$ \\
\hline$P$-value & 0.51 & 0.91 & 0.76 & $<0.01$ & \\
\hline $\mathrm{P} / \mathrm{AI}$ at $\mathrm{d} 32^{1}$ & $40.8^{\mathrm{b}}$ & $55.3^{\mathrm{a}}$ & $36.5^{\mathrm{b}}$ & $39.1^{\mathrm{b}}$ & $<0.01$ \\
\hline $8 \mathrm{~d}$ & $42.4(14 / 33)^{\mathrm{ab}}$ & $55.6(121 / 217)^{\mathrm{a}}$ & $34.7(21 / 60)^{\mathrm{b}}$ & $33.0(14 / 42)^{\mathrm{b}}$ & $<0.01$ \\
\hline $9 \mathrm{~d}$ & $39.4(13 / 33)^{\mathrm{y}}$ & $55.1(98 / 178)^{a, x}$ & $38.2(26 / 68)^{\mathrm{b}}$ & $43.3(26 / 60)^{\mathrm{ab}}$ & 0.05 \\
\hline$P$-value & 0.53 & 0.89 & 0.71 & 0.32 & \\
\hline $\mathrm{P} / \mathrm{AI}$ at $\mathrm{d} 60^{1}$ & $37.2^{\mathrm{y}}$ & $49.1^{\mathrm{a}, \mathrm{x}}$ & $29.6^{\mathrm{b}}$ & $33.8^{\mathrm{b}}$ & $<0.01$ \\
\hline $8 \mathrm{~d}$ & $38.8(13 / 33)^{\mathrm{ab}}$ & $47.5(105 / 217)^{\mathrm{a}}$ & $25.6(16 / 60)^{\mathrm{b}}$ & $25.5(11 / 42)^{\mathrm{b}}$ & $<0.01$ \\
\hline $9 \mathrm{~d}$ & $36.4(12 / 33)^{\mathrm{y}}$ & $51.7(92 / 178)^{a, x}$ & $33.8(23 / 68)^{\mathrm{b}}$ & $40.0(24 / 60)^{\mathrm{ab}}$ & 0.04 \\
\hline$P$-value & 0.56 & 0.51 & 0.38 & 0.15 & \\
\hline Pregnancy loss ${ }^{1}$ & 7.9 & 10.4 & 17.3 & 12.7 & 0.52 \\
\hline $8 \mathrm{~d}$ & $7.7(1 / 14)$ & $14.4(16 / 121)$ & $22.8(5 / 21)$ & $22.0(3 / 14)$ & 0.54 \\
\hline $9 \mathrm{~d}$ & $8.9(1 / 13)$ & $6.2(6 / 98)$ & $11.8(3 / 26)$ & $7.9(2 / 26)$ & 0.81 \\
\hline$P$-value & 0.96 & 0.08 & 0.28 & 0.22 & \\
\hline
\end{tabular}

${ }_{\mathrm{a}, \mathrm{b}}$ Values within a row with different superscript letters differ $(P<0.05)$.

${ }^{\mathrm{x}, \mathrm{y}}$ Values within a row with different superscript letters tended to differ $(0.05<P \leq 0.1)$.

${ }^{1}$ Cows with no corpus luteum on $\mathrm{d} 0$ and 1 or more visible corpus luteum on $\mathrm{d} 7$ were considered synchronized and were used in this analysis. 
Table 4. Effects of expression of estrus on estrous cycle synchronization, progesterone on d 7, pregnancy per $\mathrm{AI}(\mathrm{P} / \mathrm{AI})$ at $\mathrm{d} 32$ and 60 , and pregnancy loss from 32 to $60 \mathrm{~d}$ in synchronized cows (LSM \pm SEM with $\mathrm{n} / \mathrm{n}$ in parentheses)

\begin{tabular}{lccr}
\hline & \multicolumn{2}{c}{ Estrus } & \\
\cline { 2 - 3 } Item & No & Yes & P-value \\
\hline Ovulatory follicle diameter $^{1}(\mathrm{~mm})$ & $14.6 \pm 0.37$ & $14.8 \pm 0.33$ & 0.69 \\
Estrous cycle synchronization $^{1}$ & $81.0(202 / 248)$ & $97.4(489 / 501)$ & $<0.01$ \\
${\text { Progesterone on d } 7^{1}}^{\text {P/AI at d 32 }}$ & $2.77 \pm 0.17$ & $3.22 \pm 0.16$ & $<0.01$ \\
P/AI at d 60 & $39.4(81 / 202)$ & $51.2(252 / 489)$ & $<0.01$ \\
Pregnancy loss $^{1}$ & $31.1(66 / 202)$ & $46.3(230 / 489)$ & $<0.01$ \\
Pregnancy loss $^{1}$ & $19.8(15 / 81)$ & $9.3(22 / 252)$ & $<0.01$ \\
No heat stress $_{\text {With heat stress }}$ & $10.7(6 / 56)$ & $7.6(14 / 185)$ & 0.45 \\
$P$-value & $36.0(9 / 25)$ & $14.3(8 / 57)$ & 0.02 \\
\hline
\end{tabular}

${ }^{1}$ Cows with no corpus luteum on d 0 and 1 or more visible corpus luteum on $\mathrm{d} 7$ were considered synchronized and were used in this analysis.

percentage of cows with a CL on d 7 [91.3 (180/196) vs. $91.4 \%(487 / 527)]$ and similar P/AI in synchronized cows at $32 \mathrm{~d}[44.6(82 / 180)]$ vs. $49.2 \%(241 / 487) ; P=$ 0.38] compared with cows without detected heat stress (all measurements $\leq 39.0^{\circ} \mathrm{C}$ ), respectively. However, at the d 60 pregnancy diagnosis, lower P/AI $(P<0.01)$ was observed in cows with at least one temperature measurement $>39.0^{\circ} \mathrm{C}[33.2(65 / 180)$ vs. $44.6 \%(221 / 487)]$. This was due to greater $(P<0.01)$ pregnancy loss in cows with detected heat stress $[23.8(17 / 82)$ vs. $9.4 \%$ $(20 / 241)]$. An interaction of estrus and heat stress was detected on pregnancy loss from 32 to $60 \mathrm{~d}(P=0.04)$, in which heat-stressed cows that did not show estrus had the greatest pregnancy loss (Table 4).

A tendency $(P=0.06)$ was observed for the $\mathrm{P} 4$ concentration $7 \mathrm{~d}$ after TAI to have an effect on $\mathrm{P} /$ AI. Increasing P4 concentrations on d 7 after AI was associated with increasing P/AI (Figure 6).

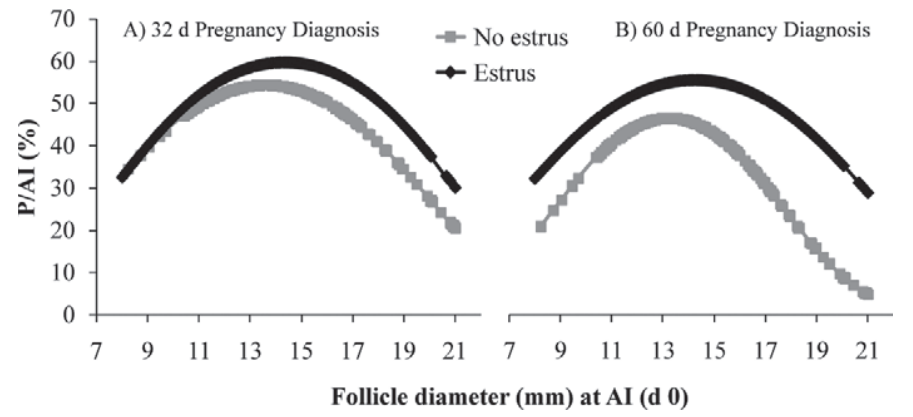

Figure 4. Effect of expression of estrus and follicle diameter at time of $\mathrm{AI}(\mathrm{d} 0)$ on pregnancy per $\mathrm{AI}(\mathrm{P} / \mathrm{AI})$ rate at 32 (panel $\mathrm{A}$ ) and $60 \mathrm{~d}$ (panel B) pregnancy diagnosis in dairy cows that had their estrous cycle synchronized (corpus luteum on d 7). Significance was set at $P=0.09$ for $32 \mathrm{~d}$ with no estrus, $P<0.01$ for $32 \mathrm{~d}$ with estrus, $P=$ 0.03 for 60 with no estrus, and $P<0.01$ for 60 with estrus.

\section{DISCUSSION}

The current study evaluated whether increasing the length of time with reduced circulating $\mathrm{P} 4$ would increase fertility in a TAI program that used E2 and P4 to synchronize the estrous cycle of cycling lactating dairy cows. The use of only lactating cows with a CL at the beginning of the protocol during the cooler months of the year produced a high percentage of cows that responded to the protocols with ovulation $(>90 \%)$ and excellent fertility $(>40 \%)$. We postulated that increasing the length of time from $\mathrm{PGF}_{2 \alpha}$ treatment until TAI by $1 \mathrm{~d}$ would allow more time for follicle development and thereby increase expression of estrus and follicle diameter at the time of AI. Consistent with this hypothesis, an increase was observed in the percentage of cows detected in estrus in the longer compared with the shorter protocol. Expression of estrus was associated with better synchronization and reduced pregnancy losses from 32 to $60 \mathrm{~d}$. Nevertheless, no detectable increase in follicle diameter was noted, although the

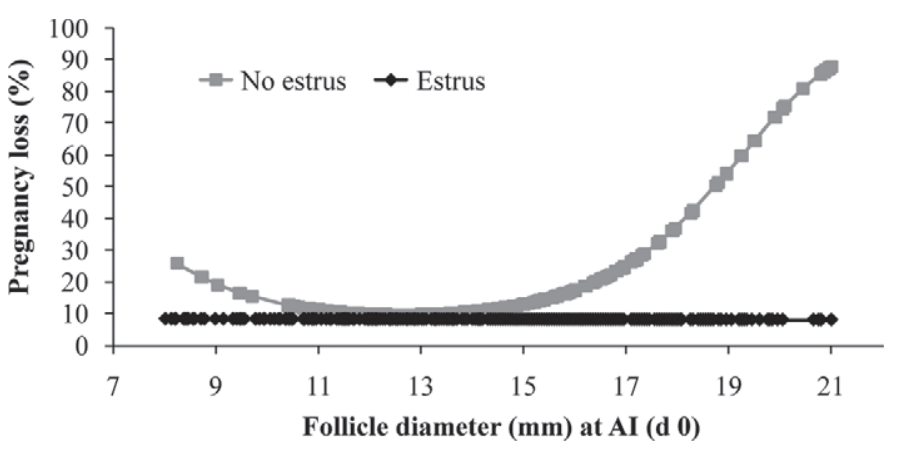

Figure 5. Effect of expression of estrus and follicle diameter at time of AI ( $\mathrm{d} 0$ ) on pregnancy loss between 32 and $60 \mathrm{~d}$ in dairy cows that had a synchronized estrous cycle (corpus luteum on $\mathrm{d} 7$ ). Significance was set at $P=0.01$ for no estrus and $P=0.97$ for estrus. 


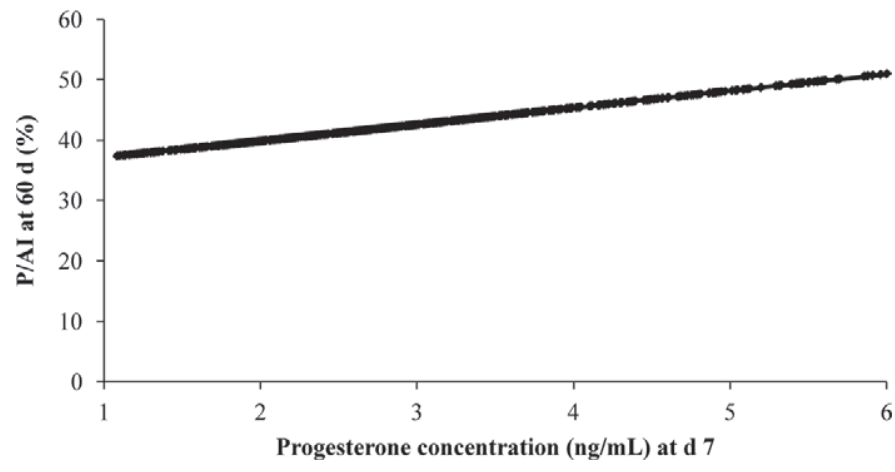

Figure 6. Effect of progesterone concentration on d 7 after AI on pregnancy per $\mathrm{AI}(\mathrm{P} / \mathrm{AI})$ rate at $60 \mathrm{~d}$ in synchronized dairy cows with progesterone $\geq 1.0 \mathrm{ng} / \mathrm{mL}$ on $\mathrm{d} 7 ; P=0.06$.

distribution of follicle sizes was altered. Our main hypothesis was that the longer protocol would result in greater fertility. Although, no overall change in P/AI was detected, we observed a decrease in pregnancy loss from 32 to $60 \mathrm{~d}$ with the longer protocol. This result highlights the importance of pregnancy loss as a critical reproductive measure in lactating dairy cows, and the strong association we detected between pregnancy loss and lack of estrus, as well as greater follicle size, potentially facilitates a greater understanding of the underlying causes of pregnancy loss. Our final hypothesis, that follicle size at TAI would be associated with differences in fertility, was clearly supported by our results with ovulation of larger and smaller follicles associated with reduced fertility. Thus, increasing protocol length from 8 to $9 \mathrm{~d}$ seemed to have a positive effect, with increased expression of estrus and reduced pregnancy loss; however, variation in responses of individual cows to either protocol resulted in a substantial number of cows that did not express estrus and did not have optimal follicle size. Examination of more than 700 cows for some individual ovarian, hormonal, and reproductive measures provides some insight into potential future improvements that could be made in these protocols.

The majority of cows expressed estrus during the protocols $(70 \% ; 411 / 590)$, even cows that ovulated smaller follicles ( $\leq 11 \mathrm{~mm} ; 76 \%$; 50/66), probably due to the ECP treatment used to induce ovulation at the end of the protocol. Our previous research has demonstrated that cows induced to ovulate with ECP have increased expression of estrus compared with cows induced to ovulate with GnRH (Pereira et al., 2013b). In addition, increasing the protocol length increased expression of estrus (63 vs. $73 \%$ for $8 \mathrm{~d}$ and $9 \mathrm{~d}$, respectively), possibly due to greater endogenous E2 production or reduced circulating P4 near TAI. The longer protocol would allow greater time for follicle growth, possibly increasing E2, and greater time for CL regression, reducing circulating P4 (Pereira et al., 2013a).

Of particular importance, expression of estrus was associated with greater fertility in our study, consistent with previous observations of improved fertility in cows showing estrus during TAI protocols (Pancarci et al., 2002; Kasimanickam et al., 2005; Souza et al., 2007). For example, in the Heatsynch protocol (d $-10 \mathrm{GnRH}$, $\mathrm{d}-3 \mathrm{PGF}_{2 \alpha}, \mathrm{d}-2 \mathrm{ECP}$, and $\mathrm{d} 0 \mathrm{TAI}$ ), cows that displayed estrus after the ECP treatment had greater P/ AI $[42.5 \%$ (306)] than cows that did not display estrus $[21.1 \%(71)]$ at TAI (Cerri et al., 2004). In a different study using the Heatsynch protocol, expression of estrus improved P/AI at 27 (43.6 vs. $17.0 \%$; $P<$ $0.01)$ and $41 \mathrm{~d}$ (36.6 vs. $12.0 \% ; P<0.01)$ compared with cows not detected in estrus (Galvão et al., 2004). Additionally, cows displaying estrus in programs with Co-Synch at 48 or $72 \mathrm{~h}$ after the $\mathrm{PGF}_{2 \alpha}$ treatment had greater P/AI at 40 (54.7 vs. 31.5\%) and $68 \mathrm{~d}$ (53.3 vs. $31.5 \%$ ) after AI (Hillegass et al., 2008). In our study, the improvement in fertility at $32(\sim 30 \%$ more pregnancies; 51.2/39.4) and $60 \mathrm{~d}(\sim 50 \%$ more pregnancies; $46.3 / 31.1$ ) was substantial. Previously, Ribeiro et al., (2012) altered the length of proestrus by changing the interval to GnRH treatment and TAI in a 5-d Ovsynch protocol from $72 \mathrm{~h}$ after $\mathrm{PGF}_{2 \alpha}$ treatment (Cos 72) compared with $58 \mathrm{~h}$ (Cos 58). Greater length of proestrus increased E2 concentrations near TAI $(P=0.04)$, but did not affect $\mathrm{P} / \mathrm{AI}$ at $\mathrm{d} 30$; however, at the $\mathrm{d}$ 65 pregnancy diagnosis, Cos 72 had greater fertility than $\operatorname{Cos} 58(P<0.05)$. We also observed a major reduction $(\sim 50 \% ; 19.8 / 9.3)$ of pregnancy loss in cows that showed estrus in our study. Similarly, Galvão et al. (2004) reported that cows detected in estrus had lower pregnancy loss than cows not in estrus [16.1 (224) vs. $29.6 \%$ (27) for estrus and no estrus, respectively]. In addition, in a previous study done during summer heat stress in Brazil, reduced pregnancy loss $(P=0.05)$ was observed for an E2 and P4 protocol that used ECP to synchronize ovulation [11\% (16/135)] compared with the 5-d Cosynch protocol that uses GnRH to synchronize ovulation $[19.6 \%(24 / 119)]$. Our study did not allow us to determine the mechanism that results in lower fertility and greater pregnancy loss in cows that did not demonstrate estrus. It is intriguing to speculate that insufficient E2 near TAI may alter uterine gene and protein expression, producing an environment that is less compatible with maintenance of pregnancy, as previously described in various species (Miller et al., 1977; Bartol et al., 1981; Buhi, 2002). A recent study in beef cattle has shown an effect of E2 near TAI on P/AI at the $\mathrm{d} 27$ pregnancy diagnosis, but did not observe an effect of E2 on subsequent pregnancy loss (Jinks et al., 
2013). However, a recent study in ovariectomized beef cattle reported that cows that did not receive E2 in the preovulatory period maintained pregnancy until d 19, based on expression of interferon tau-stimulated gene expression; by d 29, though, they had reduced pregnancies compared with cows that received either ECP or EB to increase circulating E2 during the preovulatory period (Roberts et al., 2012). It seems possible that the high pregnancy loss observed in dairy cows compared with beef cattle may be due to high E2 metabolism and reduced E2 concentrations near estrus or timed ovulation in lactating dairy cows (Sangsritavong et al., 2002; Vasconcelos et al., 2003; Wiltbank et al., 2006). Greater sensitivity of the uterine environment in a lactating dairy cow to the preovulatory effects of E2 might also explain the differences. In our study, ECP was given to increase circulating E2 in the preovulatory period; however, added E2 from the follicle may be required to produce estrus and an optimal uterine environment. Alternatively, a greater time for CL regression and reduced circulating P4 near TAI may increase expression of estrus and potentially improve pregnancy maintenance by enhancing the uterine environment. Development of more optimized protocols, potentially demonstrated by increased expression of estrus, should improve P/AI and reduce pregnancy losses.

Optimization of ovulatory follicle size has been an important objective in development of protocols that use either GnRH or E2 to synchronize ovulation near TAI (Perry et al., 2005; Souza et al., 2009; Pereira et al., 2013b). In the present study, an effect of follicle diameter on fertility was observed in either protocol. Consistent with previous studies (Vasconcelos et al., 2001; Souza et al., 2007; Wiltbank et al., 2011a), fertility was reduced for cows that ovulate smaller follicles $(<11 \mathrm{~mm})$ and larger follicles $(>17 \mathrm{~mm})$. This effect of follicle diameter was detected at both $\mathrm{d} 32$ and 60 pregnancy diagnoses, in both treatment protocols, and in cows with or without expression of estrus.

Induced ovulation of small follicles using GnRH was associated with reduced fertility, reduced circulating E2 concentrations before AI, reduced P4 concentrations after AI, and an increased percentage of cows exhibiting short luteal phases following AI (Vasconcelos et al., 2001). In beef cattle, GnRH-induced ovulation of smaller follicles $(<11.3 \mathrm{~mm})$ resulted in reduced circulating E2 at AI, reduced P/AI, and greater pregnancy loss (Perry et al., 2005). In contrast to GnRH-induced ovulation, pregnancy outcome following spontaneous estrus and ovulation was not affected by follicle diameter (Perry et al., 2005). In our study, relatively few cows $(<10 \%)$ ovulated small follicles $(\leq 11 \mathrm{~mm})$, and these cows tended to have lower P/AI. Recent research in which single embryos were collected and transferred in beef cows induced to ovulate either smaller or larger follicles using GnRH (Atkins et al., 2013; Jinks et al., 2013) showed that the concentration of $\mathrm{E} 2$ at GnRHinduced ovulation (second $\mathrm{GnRH}$ ) in the recipient cows was one of the most important factors that determined pregnancy outcome (Atkins et al., 2013). Similarly, circulating E2 at GnRH-induced ovulation (second $\mathrm{GnRH}$ ) in the recipient cows, but not the donor cows, was predictive of pregnancy success at d 27 of gestation (Jinks et al., 2013). Additionally, administration of ECP $24 \mathrm{~h}$ before AI increased pregnancy success in cows induced to ovulate a smaller dominant follicle $(<12.2 \mathrm{~mm})$. Thus, the primary benefit of increased preovulatory E2 is mediated through alterations in the maternal environment of the recipient cows. Whether the inadequate E2 is responsible for reduced reproductive success in lactating dairy cows ovulating smaller follicles following an ECP-induced ovulation remains to be determined.

Alternatively, ovulation of larger follicles is also associated with reduced fertility in lactating dairy cows (Townson et al., 2002; Bleach et al., 2004; Cerri et al., 2009). An interesting paradox is that ovulation of a larger follicle is associated with lower fertility, but is also associated with greater circulating P4 after AI. Greater P4 after AI has, at times, been associated with greater fertility (Demetrio et al., 2007, Wiltbank et al., 2011b, Forro et al., 2012). Optimization of follicle size in TAI programs is clearly an intricate balance between oocyte quality, adequate circulating E2 near AI, and adequate circulating $\mathrm{P} 4$ after AI.

Surprisingly, pregnancy loss was not associated with ovulation of smaller follicles $(<11 \mathrm{~mm})$, but was more associated with ovulation of larger follicles, particularly in the absence of expression of estrus and reduced length of the protocol. Previous studies have shown reduced or a tendency for reduction in pregnancy loss in cows with expression of estrus (Pereira et al., 2013b), greater circulating E2 near TAI (Souza et al., 2007; Hillegass et al., 2008; Souza et al., 2011), greater circulating P4 before AI (Wiltbank et al., 2011b), and increased length of proestrus (Ribeiro et al., 2012). In the present study, cows that showed estrus had decreased pregnancy losses in cows ovulating all sizes of follicles, even though an effect of follicle size on P/AI was observed using either the $\mathrm{d} 32$ or 60 pregnancy diagnosis. However, the high pregnancy loss in cows that did not show estrus was primarily due to excessive pregnancy loss in cows that ovulated large follicles. In contrast, in a recent study in our laboratory, high pregnancy loss in a GnRH-based protocol was clearly associated with ovulation of smaller follicles (Pereira et al., 2013b). One possible explanation for this unexpected result is that the high pregnancy loss may be due to an interaction of 
less than optimal embryo (ovulation of larger follicle) with a less than optimal uterine environment (lack of estrus and reduced E2). This intriguing but speculative idea should be pursued in future research.

Cows with heat stress $\left(>39.1^{\circ} \mathrm{C}\right)$ had greater pregnancy losses $[23.8 \%(17 / 82)]$ than cows without heat stress $[9.4 \%(20 / 241)]$. It is well-established that heat stress can reduce fertility in lactating cows (Vasconcelos et al., 2006; Vasconcelos et al., 2011a; Vasconcelos et al., 2011b; Vasconcelos et al., 2011c). In heat-stressed cows, expression of estrus was associated with reduced pregnancy loss, but expression of estrus did not affect pregnancy loss in non-heat-stressed cows. Our previous results were consistent with E2 near TAI having a positive effect on pregnancy maintenance in heat-stressed cows (Pereira et al., 2013b).

In conclusion, increasing the length of an E2 and $\mathrm{P} 4$-based TAI protocol increased expression of estrus and reduced pregnancy loss. Although no overall effect of protocol length on P/AI was observed, clear effects of size of the ovulatory follicle and expression of estrus on $\mathrm{P} / \mathrm{AI}$ were noted. Our results indicate that improvements in fertility and reductions in pregnancy loss are likely in E2 and P4-based TAI protocols by optimizing the ovulatory follicle diameter, increasing expression of estrus, and optimization of proestrous hormonal environment.

\section{REFERENCES}

Atkins, J. A., M. F. Smith, M. D. Macneil, E. M. Jinks, F. M. Abreu, L. J. Alexander, and T. W. Geary. 2013. Pregnancy establishment and maintenance in cattle. J. Anim. Sci. 91:722-733.

Bartol, F. F., W. W. Thatcher, G. S. Lewis, E. L. Bliss, M. Drost, and F. W. Bazer. 1981. Effect of estradiol-17beta on PGF and total protein content in bovine uterine flushings and peripheral plasma concentration of 13, 14-dihydro-15-keto-PGF(2alpha). Theriogenology 15:345-358.

Berman, A., Y. Folman, M. Kaim, M. Mamen, Z. Herz, D. Wolfenson, A. Arieli, and Y. Graber. 1985. Upper critical temperatures and forced ventilation effects for high-yielding dairy cows in a subtropical climate. J. Dairy Sci. 68:1488-1495.

Bleach, E. C., R. G. Glencross, and P. G. Knight. 2004. Association between ovarian follicle development and pregnancy rates in dairy cows undergoing spontaneous oestrous cycles. Reproduction 127:621-629.

Bridges, G. A., M. L. Mussard, C. R. Burke, and M. L. Day. 2010. Influence of the length of proestrus on fertility and endocrine function in female cattle. Anim. Reprod. Sci. 117:208-215.

Buhi, W. C. 2002. Characterization and biological roles of oviduct-specific, oestrogen-dependent glycoprotein. Reproduction 123:355362.

Cerri, R. L., J. E. Santos, S. O. Juchem, K. N. Galvão, and R. C. Chebel. 2004. Timed artificial insemination with estradiol cypionate or insemination at estrus in high-producing dairy cows. J. Dairy Sci. 87:3704-3715

Cerri, R. L., H. M. Rutigliano, R. C. Chebel, and J. E. Santos. 2009 Period of dominance of the ovulatory follicle influences embryo quality in lactating dairy cows. Reproduction 137:813-823.

Demetrio, D. G., R. M. Santos, C. G. Demetrio, and J. L. M. Vasconcelos. 2007. Factors affecting conception rates following artificial insemination or embryo transfer in lactating Holstein cows. J Dairy Sci. 90:5073-5082.

FASS. 1999. Guide for the Care and Use of Agricultural Animals in Agricultural Research and Teaching. 1st ed. Federation of Animal Science Societies, Savoy, IL.

Forro, A., G. Tsousis, N. Beindorff, R. Sharifi, L. Jäkel, and H. Bollwein. 2012. Combined use of Ovsynch and progesterone supplementation after artificial insemination in dairy cattle. J. Dairy Sci. 95:4372-4381.

Galvão, K. N., J. E. Santos, S. O. Juchem, R. L. Cerri, A. C. Coscioni, and M. Villaseñor. 2004. Effect of addition of a progesterone intravaginal insert to a timed insemination protocol using estradiol cypionate on ovulation rate, pregnancy rate, and late embryonic loss in lactating dairy cows. J. Anim. Sci. 82:3508-3517.

Giordano, J. O., M. C. Wiltbank, J. N. Guenther, R. Pawlisch, S. Bas, A. P. Cunha, and P. M. Fricke. 2012. Increased fertility in lactating dairy cows resynchronized with Double-Ovsynch compared with Ovsynch initiated $32 \mathrm{~d}$ after timed artificial insemination. J. Dairy Sci. 95:639-653

Hillegass, J., F. S. Lima, M. F. Sá Filho, and J. E. Santos. 2008. Effect of time of artificial insemination and supplemental estradiol on reproduction of lactating dairy cows. J. Dairy Sci. 91:4226-4237.

Jinks, E. M., M. F. Smith, J. A. Atkins, K. G. Pohler, G. A. Perry, M. D. Macneil, A. J. Roberts, R. C. Waterman, L. J. Alexander, and T. W. Geary. 2013. Preovulatory estradiol and the establishment and maintenance of pregnancy in suckled beef cows. J. Anim. Sci. 91:1176-1185.

Kasimanickam, R., J. M. Cornwell, and R. L. Nebel. 2005. Fertility following fixed-time AI or insemination at observed estrus in Ovsynch and Heatsynch programs in lactating dairy cows. Theriogenology 63:2550-2559.

Martins, J. P., R. K. Policelli, L. M. Neuder, W. Raphael, and J. R. Pursley. 2011. Effects of cloprostenol sodium at final prostaglandin $\mathrm{F}_{2 \alpha}$ of Ovsynch on complete luteolysis and pregnancy per artificial insemination in lactating dairy cows. J. Dairy Sci. 94:2815-2824.

Meneghetti, M., O. G. Sá Filho, R. F. Peres, G. C. Lamb, and J. L. M. Vasconcelos. 2009. Fixed-time artificial insemination with estradiol and progesterone for Bos indicus cows. I: Basis for development of protocols. Theriogenology 72:179-189.

Miller, B. G., N. W. Moore, L. Murphy, and G. M. Stone. 1977. Early pregnancy in the ewe: Effects of oestradiol and progesterone on uterine metabolism and on embryo survival. Aust. J. Biol. Sci. 30:279-288.

NRC. 2001. Nutrient Requirements of Dairy Cattle. No. 7. Natl. Acad. Press, Washington, DC.

Pancarci, S. M., E. R. Jordan, C. A. Risco, M. J. Schouten, F. L. Lopes, F. Moreira, and W. W. Thatcher. 2002. Use of estradiol cypionate in a presynchronized timed artificial insemination program for lactating dairy cattle. J. Dairy Sci. 85:122-131.

Pereira, M. H., C. P. Sanches, T. G. Guida, A. D. Rodrigues, F. L. Aragon, M. B. Veras, P. T. Borges, M. C. Wiltbank, and J. L. M Vasconcelos. 2013a. Timing of prostaglandin $\mathrm{F}_{2 \alpha}$ treatment in an estrogen-based protocol for timed artificial insemination or timed embryo transfer in lactating dairy cows. J. Dairy Sci. 96:28372846.

Pereira, M. H. C., A. D. P. Rodrigues, T. Martins, W. V. C. Oliveira, P. S. A. Silveira, M. C. Wiltbank, and J. L. M. Vasconcelos. 2013b. Timed artificial insemination programs during summer in lactating dairy cows: Comparison of the 5 -d Cosynch protocol with an estrogen/progesterone-based protocol. J. Dairy Sci. 96:69046914. http://dx.doi.org/10.3168/jds.2012-6260.

Peres, R. F., I. Claro, O. G. Sá Filho, G. P. Nogueira, and J. L. M. Vasconcelos. 2009. Strategies to improve fertility in Bos indicus postpubertal heifers and nonlactating cows submitted to fixedtime artificial insemination. Theriogenology 72:681-689.

Perry, G. A., M. F. Smith, M. C. Lucy, J. A. Green, T. E. Parks, M. D. MacNeil, A. J. Roberts, and T. W. Geary. 2005. Relationship between follicle size at insemination and pregnancy success. Proc. Natl. Acad. Sci. USA 102:5268-5273.

Peters, M. W., and J. R. Pursley. 2003. Timing of final GnRH of the Ovsynch protocol affects ovulatory follicle size, subsequent luteal 
function, and fertility in dairy cows. Theriogenology 60:11971204.

Pursley, J. R., M. R. Kosorok, and M. C. Wiltbank. 1997. Reproductive management of lactating dairy cows using synchronization of ovulation. J. Dairy Sci. 80:301-306

Ribeiro, E. S., A. P. Monteiro, F. S. Lima, H. Ayres, R. S. Bisinotto, M. Favoreto, L. F. Greco, R. S. Marsola, W. W. Thatcher, and J. E. Santos. 2012. Effects of presynchronization and length of proestrus on fertility of grazing dairy cows subjected to a 5-day timed artificial insemination protocol. J. Dairy Sci. 95:2513-2522.

Roberts, C., G. Perry, M. Minten, A. Roberts, M. Macneil, and T. Geary. 2012. Effects of preovulatory estradiol concentration on embryo survival and pregnancy establishment in beef cows. Pages 98-102 in Proc. West. Sect. Am. Soc. Anim. Sci. vol. 63. Am. Soc. Anim. Sci., Champaign, IL.

Sangsritavong, S., D. K. Combs, R. Sartori, L. E. Armentano, and M. C. Wiltbank. 2002. High feed intake increases liver blood flow and metabolism of progesterone and estradiol-17beta in dairy cattle. J. Dairy Sci. 85:2831-2842.

Santos, R. and J. L. M. Vasconcelos. 2006. Concentrate intake and plasmatic progesterone concentration in Holstein cows. Arquivo Brasileiro Med. Veterinaria Zootecnia 58:1162-1167.

Souza, A. H., A. Gümen, E. P. Silva, A. P. Cunha, J. N. Guenther, C. M. Peto, D. Z. Caraviello, and M. C. Wiltbank. 2007. Supplementation with estradiol-17beta before the last gonadotropin-releasing hormone injection of the Ovsynch protocol in lactating dairy cows. J. Dairy Sci. 90:4623-4634.

Souza, A. H., S. Viechnieski, F. A. Lima, F. F. Silva, R. Araújo, G. A. Bó, M. C. Wiltbank, and P. S. Baruselli. 2009. Effects of equine chorionic gonadotropin and type of ovulatory stimulus in a timedAI protocol on reproductive responses in dairy cows. Theriogenology $72: 10-21$.

Souza, A. H., E. P. Silva, A. P. Cunha, A. Gümen, H. Ayres, D. J. Brusveen, J. N. Guenther, and M. C. Wiltbank. 2011. Ultrasonographic evaluation of endometrial thickness near timed AI as a predictor of fertility in high-producing dairy cows. Theriogenology 75:722-733.

Townson, D. H., P. C. Tsang, W. R. Butler, M. Frajblat, L. C. Griel, C. J. Johnson, R. A. Milvae, G. M. Niksic, and J. L. Pate. 2002. Relationship of fertility to ovarian follicular waves before breeding in dairy cows. J. Anim. Sci. 80:1053-1058.

Vasconcelos, J. L. M., R. Sartori, H. N. Oliveira, J. G. Guenther, and M. C. Wiltbank. 2001. Reduction in size of the ovulatory follicle reduces subsequent luteal size and pregnancy rate. Theriogenology $56: 307-314$.

Vasconcelos, J. L. M., S. Sangsritavong, S. J. Tsai, and M. C. Wiltbank. 2003. Acute reduction in serum progesterone concentrations after feed intake in dairy cows. Theriogenology 60:795-807.

Vasconcelos, J. L. M., D. G. Demétrio, R. M. Santos, J. R. Chiari, C. A. Rodrigues, and O. G. Sá Filho. 2006. Factors potentially affecting fertility of lactating dairy cow recipients. Theriogenology 65:192-200.

Vasconcelos, J. L. M., D. T. Jardina, O. G. Sá Filho, F. L. Aragon, and M. B. Veras. 2011a. Comparison of progesterone-based protocols with gonadotropin-releasing hormone or estradiol benzoate for timed artificial insemination or embryo transfer in lactating dairy cows. Theriogenology 75:1153-1160.

Vasconcelos, J. L. M., O. G. Sá Filho, P. L. Justolin, P. Morelli, F. L. Aragon, M. B. Veras, and S. Soriano. 2011b. Effects of postbreeding gonadotropin treatments on conception rates of lactating dairy cows subjected to timed artificial insemination or embryo transfer in a tropical environment. J. Dairy Sci. 94:223-234.

Vasconcelos, J. L. M., R. F. Cooke, D. T. Jardina, F. L. Aragon, M. B. Veras, S. Soriano, N. Sobreira, and A. B. Scarpa. 2011c. Associations among milk production and rectal temperature on pregnancy maintenance in lactating recipient dairy cows. Anim. Reprod. Sci. 127:140-147.

West, J. W. 2003. Effects of heat-stress on production in dairy cattle. J. Dairy Sci. 86:2131-2144

Wildman, E. E., G. M. Jones, P. E. Wagner, R. L. Boman, H. F. Troutt, and T. N. Lesch. 1982. A dairy cow body condition scoring system and its relationship to selected production characteristics. J. Dairy Sci. 65:495-501.

Wiltbank, M., H. Lopez, R. Sartori, S. Sangsritavong, and A. Gümen. 2006. Changes in reproductive physiology of lactating dairy cows due to elevated steroid metabolism. Theriogenology 65:17-29.

Wiltbank, M. C., R. Sartori, M. M. Herlihy, J. L. Vasconcelos, A. B. Nascimento, A. H. Souza, H. Ayres, A. P. Cunha, A. Keskin, J. N. Guenther, and A. Gumen. 2011a. Managing the dominant follicle in lactating dairy cows. Theriogenology 76:1568-1582.

Wiltbank, M. C., A. H. Souza, P. D. Carvalho, R. W. Bender, and A. B. Nascimento. 2011b. Improving fertility to timed artificial insemination by manipulation of circulating progesterone concentrations in lactating dairy cattle. Reprod. Fertil. Dev. 24:238-243. 